\title{
Landslides
}

Volume 4, Number 4 / décembre 2007, 297-309

Archimer, archive institutionnelle de l'Ifremer http://dx.doi.org/10.1007/s10346-007-0086-z

(c) Springer 2007. Part of Springer Science+Business

Media

The original publication is available at http://www.springerlink.com

\section{The role of sedimentation rate and permeability in the slope stability of the formerly glaciated Norwegian continental margin: the Storegga slide model}

\author{
Didier Leynaud ${ }^{1,3,}{ }^{*}$, Nabil Sultan ${ }^{2}$ and Jürgen Mienert ${ }^{1}$
}

\author{
${ }^{1}$ Department of Geology, University of Tromso, 9037 Tromso, Norway \\ ${ }^{2}$ Ifremer DRO/GM BP70 29280, Plouzané, France \\ ${ }^{3}$ Present address: Ifremer, Géosciences Marines, 29280 Plouzané, France \\ *: Corresponding author : Didier Leynaud, Email: dleynaud@ifremer.fr
}

\begin{abstract}
:
Despite the gently dipping slopes (ca $1^{\circ}$ ), large-scale submarine slope failures have occurred on the mid-Norwegian continental margin (Storegga, Sklinnadjupet, Traenadjupet), suggesting the presence of special conditions predisposing to failure in this formerly glaciated margin. With a volume estimated between 2,400 and 3,200 km3 and an affected area of approximately 95,000 km2, the Storegga slide represents one of the largest and best-studied submarine slides of Holocene age known worldwide. Finite element modeling of slope failure indicates that a large $(6.5<M s<7.0)$ seismic triggering mechanism would not be sufficient to cause failure at more than $110 \mathrm{~m}$ below the seabed as observed for the slip planes at Storegga (northern sidewall). This implies that other factors (e.g., liquefaction, strain softening, gas charging, rapid burial) are needed to explain the occurrence of the Storegga slide with a deep surface of failure. In this paper, we discuss the importance of the compaction effect of rapidly accumulated sediments in the slide area. During compaction, sediment grains reorganize themselves, thereby, expelling pore water. Consequently, depending on sedimentation rate and permeability, excess pore pressures might result beneath less permeable sediments. Our modeling and cross-checking illustrate how excess pore pressure generation due to high sedimentation rate could explain the development of layers of weakness, and thus, how such a large slide might have been initiated in deep sediments. Using the highest sedimentation rate estimated in the area (36 and $27 \mathrm{~m} / \mathrm{kyr}$ between 16.2 and $15 \mathrm{kyr}$ BP), 1D modeling shows excess pore pressure values of around $200 \mathrm{kPa}$ at a depth of $100 \mathrm{~m}$ below the seafloor $15 \mathrm{kyr} \mathrm{BP}$ and $60 \mathrm{kPa}$ at a depth of $100 \mathrm{~m}$ at the time of the slide (8 kyr BP). Excess pore pressure apparently drastically reduced the resistance of the sediment (incomplete consolidation). In addition, 2D modeling shows that permeability anisotropies can significantly affect the lateral extent of excess pore pressure dissipation, affecting, that way, normally consolidated sediments far from the excess pore pressure initiation area.
\end{abstract}

Keywords: Rapid sedimentation - Sediment overpressure - Slope stability - Submarine slide 


\section{INTRODUCTION}

Submarine mass movements play an important role in shaping the sedimentary structure of continental margins. Over the last few years, extensive research projects, often in close collaboration between academia and the offshore industry, have addressed this topic and have significantly improved our understanding of the occurrence, frequency, variability and dynamics of mass wasting processes on continental margins (Haflidason et al. 2001, 2004; Lindberg et al. 2004; Sultan et al. 2004; Solheim et al. 2005; Kvalstad et al. 2005a). The comprehension of mass wasting occurrences is also important for estimating the risk related to failure impacts for deepwater exploration activity and tsunami generation which might severely affect coastal communities (Bryn et al. 2002, 2004, 2005; Huene et al. 2001). However, many questions about the complex mechanism of slope instability on continental margins are still unresolved.

In a previous study focusing on the Storegga slide area (northern sidewall; Helland Hansen area) (Leynaud et al. 2004), it was shown by dynamic modeling that a major seismic event $(\mathrm{Ms} \geq 6.5)$ was insufficient to trigger a deep failure (110 m high sidewall observed in reality) on a slope of only $1^{\circ}$. Because earthquake-induced shear stress quickly decreases with depth, seismic acceleration is not significant in deep 
sediments, and thus it is difficult to explain the thickness of the Storegga slide by seismic loading alone. Therefore, it is apparent that additional parameters have to be considered in a slope stability assessment in order to propose a complete and realistic model for back-analysis of the earlier failure as well as for the present day slope stability. Other destabilizing factors (climate change, gas hydrate melting, gas charging of sediments, diapirism, earthquakes and liquefaction) can lead to an increase in pore pressure within the sediment, and thus to a decrease in soil strength, even though it is not always evident how to quantify these effects. Excess pore pressure (EPP) generation from rapid sedimentation is another factor predisposing the site to failure (Bryn et al. 2004; Haflidason et al. 2004; Kvalstad et al. 2005a,b) and has been proposed for various slides area off the Norwegian margin (Nyk slide, Lindberg et al. 2004; Trænadjupet slide, Laberg et al. 2003). Many other continental margins characterized by high sedimentation rates show a record of mass wasting as well, i.e. the Ebro margin (Baraza et al. 1990), the Mississipi Delta, Gulf of Mexico (Adams and Roberts 1993) and the Gulf of Alaska (von Huene et al. 2001).

Hjelstuen et al. (2004) have recently estimated a high sedimentation rate (several $10 \mathrm{~m} / \mathrm{kyr}$ ) in the Helland Hansen area at the northern part of the Storegga slide headwall. This provides an opportunity to model the EPP generation over a short time period in the immediate vicinity of the Storegga slide headwall. Firstly, EPP relative to hydrostatic pressure in consolidated sediments reduces the effective vertical stress, 
increasing the shear stress effect. Secondly, it is well known that EPP within the sediment during sedimentation is a key parameter controlling consolidation, and thus the shear strength of the deposited sediment. The consolidation process is very sensitive to parameters such as the porosity and permeability (hydraulic conductivity) distribution in the sediment. We define these parameters from sediment test profiles; however, depending on the sedimentation history and sediment variability the modeling, involving soil parameter profiles and thus EPP development, can differ from reality. Thus, the present work attempts to provide an overview of the excess pore-pressure generation in the sediment at the end of a high sedimentation rate period, as well as the pore-pressure dissipation rate after this stage. This allows us to estimate the evolution of undrained shear strength with time, and thus the control of sedimentation rate on slope stability.

\section{STOREGGA SLIDE AREA}

The Storegga slide, located to the south of the Vøring Plateau (Figure 1), stretches from the North Sea Fan to the Helland Hansen Arch: it occurred during a multi-phase event at about $8.2 \mathrm{kyr}$ BP (Haflidason et al. 2001). Numerous large-scale submarine landslides occured in the Storegga slide area during the last c. $1 \mathrm{Ma}$ and they were 
associated in time with the regular advance of glaciers towards the shelf break (Haflidason et al. 2005). This study concentrates on the north sidewall (Helland Hansen area) where geophysical indications of gas hydrates exist (Bünz et al. 2004).

The Storegga slide exhibits slip planes that follow regional seismic horizons which correspond to fine grained marine clays related to contour-current influenced sedimentation (Figure 2), similar to older slides in the region (Bryn et al. 2002). This observation suggests that slide geometry might be governed by some regional geological/geotechnical conditions instead of local factors. The slides are translational, and seabed morphology suggests a dominant retrogressive slide development (Bryn et al. 2005). The pre-glacial morphology and the glacial history play major roles in controlling the location of the slides (Bryn et al. 2002).

The sediments sampled from geoborings in this area can be placed in two main groups: glacial and marine deposits (Tjelta et al. 2002). The main observations from these sediments are summarised in Table 1. Fine-grained marine clays have distinctly lower shear strength than glacial clays (Bryn et al. 2002). Due to the higher sensitivity of the marine clays (for the same consolidation stress), they are considered to be the most susceptible lateral slip planes (Kvalstad et al. 2002). Bryn et al. (2002) concluded that high sedimentation rates and thick glacial clays caused unfavorable shear stress and EPP in underlying marine clays and that the most likely trigger mechanism was a strong earthquake. 


\section{SEDIMENTATION RATE}

The sedimentation rate in the Helland Hansen area during the last 30,000 years has been estimated using the MD99-2291 core and the corresponding seismic unit thickness observed in the area (Hjelstuen et al. 2004). Maximum sedimentation rates of $36 \mathrm{~m} / \mathrm{kyr}(16.2-15.7 \mathrm{kyr} \mathrm{BP})$ and $27 \mathrm{~m} / \mathrm{kyr}(15.7-15.0 \mathrm{kyr} \mathrm{BP})$ were found near the sidewall located to the north of the Storegga slide headwall (Figure 3). The eastern boundary of the reflection-seismic data-unit (unit between two reflection-seismic horizons) isopachs extend from the headwall northward (Figure 4). A similar or even

higher sediment contribution is likely along the headwall according to the position of the Buadjupet ice-stream inflow (Bryn et al. 2002). The main depocentres of glacial clays along the mid-Norwegian margin were the Skjoldryggen (Sklinnadjupet icestream), the Storegga slide area, the North Sea Fan and the Trænadjupet slide area.

\section{SIMPLIFIED 1-D CONSOLIDATION THEORY}

For 1-D sediment consolidation, the rate of consolidation and dissipation of EPP is defined by equation (1) (Terzaghi \& Peck 1967): 
$c_{v} \cdot \frac{\partial^{2} u_{e}}{\partial z^{2}}=\frac{\partial u_{e}}{\partial t}$

where

$c_{v}$, is the coefficient of consolidation, $u_{e}$ is the excess pore pressure (EPP), $\mathrm{z}$ is the depth of the layer, and $t$ is time.

The EPP is the pressure in excess of hydrostatic pressure which tends to drive the water through the soil to reach hydrostatic equilibrium conditions (Terzaghi \& Peck 1967). We consider the drainage path as singly drained (vertical and upward flow) as a first step. The predicted time rate for an average consolidation is given by relation (2):

$T=\frac{c_{v} \cdot t}{H_{d r}^{2}} \quad$ or $\quad t=\frac{T \cdot H_{d r}^{2}}{c_{v}}$

where $H_{d r}$, is the drainage height, $t$ is the time, and $\mathrm{T}$ is the time factor, a dimensionless parameter characterizing average consolidation.

On the condition that $K=c_{v} \cdot m_{v} \cdot \gamma_{w}=c_{v} \cdot m_{w}$ 
where $K(\mathrm{~m} / \mathrm{s})$, is soil permeability or hydraulic conductivity, $c_{v}\left(\mathrm{~m}^{2} / \mathrm{s}\right)$ is the coefficient of consolidation, $m_{v}\left(\mathrm{~m}^{2} / \mathrm{kg}\right)$ is the coefficient of volume compressibility, $\gamma_{w}\left(\mathrm{~kg} / \mathrm{m}^{3}\right)$ is the unit weight of water, and $m_{w}(1 / \mathrm{m})$ is the coefficient of volume change of the saturated soil, equation (2) becomes:

$t=\frac{T \cdot H_{d r}^{2} \cdot m_{w}}{K}$

It is worth noting that equation (3) has clear limitations for long-term consolidation during sedimentation because it does not consider that parameters change every time step (drainage path and coefficient of consolidation), and that consolidation occurs after the first loading increment and not just at the end of a complete sedimentation cycle. However, this approach provides a provisional framework for the time necessary for an average consolidation of the sediment. Table 2 shows the time required for $50 \%$ and $90 \%$ average consolidation for a 60 -m thick sediment, depending on the coefficient of volume change $m_{w}$ of the saturated sediment and various average permeabilities.

With an average permeability (hydraulic conductivity) of $1.5 \cdot 10^{-10} \mathrm{~m} / \mathrm{s}$ and an average volume change coefficient of $1.0 \cdot 10^{-2}$, the average consolidation for a $60-\mathrm{m}$ thick sediment is not complete until about $6500 \mathrm{yr}$ after the end of the deposition.

\section{CONSOLIDATION ANALYSIS USING SECO SOFTWARE}


The SeCo software (Sultan et al. 2004) models the 1-D consolidation process in sediments using the effective stress ratio (initial and final stress) to estimate the void ratio and the permeability coefficient at each time step for each depth interval. The effective stress ratio is obtained from oedometer tests.

To verify the SeCo software, EPP numerical solutions obtained were compared to the analytical solutions proposed by Gibson (1958) for different values of the $\frac{S R_{\text {Gibson }}}{2 \cdot \sqrt{C_{V}}}$ parameter (where $h=S R_{\text {Gibson }} \cdot t^{\frac{1}{2}} ; h$ is the thickness of the deposit, $t$ is the time of deposition, $S R_{\text {Gibson }}$ is the modified sedimentation rate corresponding to $t^{\frac{1}{2}}$ ). A good agreement can be observed in Figure 5 between the numerical solutions of the EPP using the SeCo software and the analytical expression of Gibson (1958). One should mention that, in the SeCo software, the compressibility index was set equal to 0.00015 to maintain a constant $\mathrm{Cv}$ (coefficient of consolidation) as this was considered in the Gibson's analytical solution.

\subsection{Theory of consolidation and dissipation of excess pore pressure}

Compaction results from sediment accumulation when sediments densify under their own weight and water is expelled. With a high sedimentation rate or a low permeability (hydraulic conductivity), high pore pressure can be generated. To model 
the evolution of consolidation, certain parameters such as sedimentation rate, porosity, permeability, and the stress state within the sediment are needed. In the following paragraph, some basic equations used to obtain these parameters are presented.

For 1-D vertical compaction, the effective vertical stress $\sigma_{v}^{\prime}$ controls the consolidation rate and EPP dissipation,

$$
\sigma_{v}^{\prime}=\sigma_{v}-u_{e}
$$

where $\sigma_{v}$ is the total stress and $u_{e}$ is the excess pore pressure. The pore fluid pressure $u$ is the sum of the hydrostatic pressure and the excess pore pressure $u_{e}$,

$$
u=u_{e}+\rho_{w} \cdot g \cdot z
$$

The void ratio is related to the vertical effective stress ratio through the relation:

$$
e=e_{o}-\lambda \cdot \ln \left(\frac{\sigma_{v}^{\prime}}{\sigma_{v o}^{\prime}}\right)
$$

where $e$ is the void ratio at the vertical effective stress $\sigma_{v}^{\prime}, e_{o}$ is the initial void ratio at 
a reference vertical effective stress $\sigma_{v o}^{\prime}$, and $\lambda$ is the compressibility index $\left(\ln =\log _{e}\right)$. Given these relations, the consolidation process depends directly on the EPP dissipation and sedimentation rate. The EPP dissipation can be modeled as (Sultan et al. 2004),

$$
\frac{\partial U}{\partial t}=\frac{\partial}{\partial z}\left[\frac{k_{i}(1-\phi)^{2}}{S_{t} \mu} \frac{\partial U}{\partial z}\right]+\left[\frac{\phi \beta}{S_{t}(1-\phi)}\right] \frac{\partial \sigma_{v}}{\partial t}
$$

where $k_{i}$, is the intrinsic permeability, $\mu$ is the fluid viscosity, $\beta$ is the bulk compressibility and $S_{t}$ is the storage coefficient. $S_{t}$ represents the volume of water absorbed or expelled by a permeable body per unit surface area per unit change in head,

$$
S_{t}=\frac{\phi \cdot \beta_{m}}{(1-\phi)}+\phi \cdot \beta_{f}
$$

where $\beta_{f}$ is the fluid compressibility and $\beta_{m}$ is the sediment matrix compressibility. When sediment accumulation is rapid and hydraulic conductivity is relatively low, pressure in excess of hydrostatic pressure develops in the sediment. Over-pressurized sediments are not completely compacted and this affects the stability of the soil. 


\subsection{Evaluation of sediment parameters}

To accurately model the sediment consolidation process, we need to quantify parameters such as void ratio, permeability (hydraulic conductivity) and the compressibility index of the saturated sediment matrix. Six oedometer test results (NGI 2000) were used to estimate permeability (hydraulic conductivity), void ratio and compressibility index down to a depth of $21 \mathrm{~m}$ (Table 3).

\subsubsection{Permeability (hydraulic conductivity) versus void ratio}

We assume that permeability is related to void ratio by the following relation:

$\ln (K)=a \cdot e+b$

where $K$ is Darcy's permeability or hydraulic conductivity $(\mathrm{m} / \mathrm{s})$, a and b are constants depending on the sediment, and $e$ is the void ratio. Using the values obtained from the oedemeter tests (boring MD99-2288) we obtained the distribution observed in Figure 6. Applying a linear regression to the values in the lower part of the graph (the minimum value corresponds to $K_{\min }=1.2 \cdot 10^{-10} \mathrm{~m} / \mathrm{s}$ with $\mathrm{OCR}=1.2$, a depth of 65 to 
$123 \mathrm{~m}$; borehole 6404/5) (NGI 1998) we obtained the relation:

$\ln (K)=1.4 \cdot e-24.3$

\subsubsection{Compressibility index and initial void ratio}

The oedometer tests performed on the boring MD99-2288 provide data about axial strain versus effective axial stress. Given that

$\varepsilon_{v}=-a \ln \left(\frac{\sigma_{v}^{\prime}}{\sigma_{v o}^{\prime}}\right)$

where $\varepsilon_{v}$ is volumetric strain, $a$ is a constant depending on the sediment, $\sigma_{v}$ is the effective axial stress to final volume after oedometer consolidation, and $\sigma_{v o}$ is the effective axial stress to initial volume before oedometer consolidation. Because

$\varepsilon_{v}=\frac{\Delta e}{1+e_{o}}$

where $\Delta e$ is the void ratio reduction during consolidation $\left(e-e_{o}\right)$ and $e_{o}$ is the initial 
void ratio, we obtain

$$
\frac{\Delta e}{1+e_{o}}=\left[-a \cdot \ln \left(\frac{\sigma_{v}^{\prime}}{\sigma_{v o}^{\prime}}\right)\right]
$$

and thus

$$
e=e_{o}-a \cdot\left(1+e_{o}\right) \cdot \ln \left[\frac{\sigma_{v}^{\prime}}{\sigma_{v o}^{\prime}}\right]
$$

or

$$
e=e_{o}-\lambda \cdot \ln \left[\frac{\sigma_{v}^{\prime}}{\sigma_{v o}^{\prime}}\right]
$$

where $\lambda=a \cdot\left(1+e_{o}\right)$. The summary of $a$ and $\lambda$ parameters are listed in Table 4 . We consider the compressibility index $\lambda$ (Figure 7) to be equal to 0.18 in order to fit a minimum porosity value of $50 \%$ at a depth of $200 \mathrm{~m}(\mathrm{WC}=38.5 \%$, a depth of $65 \mathrm{~m}$; borehole 6404/5). 


\subsection{Excess Pore Pressure Estimate}

The SeCo software numerically solves the system of equations (4)-(8) using a finite difference approximation. The upper boundary of the model is a moving boundary due to continuous sedimentation. Using the previously described high sedimentation rate with the SeCo software, we modeled EPP generation in the sediment and dissipation through the sediment column between $15 \mathrm{kyr}$ BP and 8 kyr BP (Figure 8). However, the compaction model starts at $30 \mathrm{kyr}$ BP using a lower sedimentation rate. Onedimensional modeling yields an EPP of around $140 \mathrm{kPa}$ at the end of the rapid sedimentation period (15 kyr BP; 60-m depth) and an incomplete dissipation of pressure with time $(80 \mathrm{kPa} ; 60-\mathrm{m}$ depth) at $8 \mathrm{kyr} \mathrm{BP}$ (after $7 \mathrm{kyr})$.

\section{CONSOLIDATION ANALYSIS USING BASIN 2 SOFTWARE}

We compared results from the previous SeCo consolidation model against those computed using a second software package to ensure the consistency in modeled EPP generation during the high sedimentation rate period (16,2-15,0 kyr BP) and in the EPP dissipation. This comparison was made using BASIN2 (Bethke et al. 2002), a public software package available from the University of Illinois that uses finite difference calculations. 


\subsection{Theory}

BASIN2 uses transmissivities to calculate net mass and energy fluxes at nodes in the model domain. The net fluid flux $Q(\mathrm{~m} / \mathrm{s})$ in the sediment from one node to another is calculated using hydraulic transmissivity, fluid pressure, and fluid density according to Bethke et al. (2002). Assuming fluid density is constant, the equations become,

$Q_{x}=-\tau_{x_{i, j}} \cdot\left(\Phi_{i+1, j}-\Phi_{i, j}\right)$

and

$Q_{z}=-\tau_{z_{i, j}} \cdot\left(\Phi_{i, j d}-\Phi_{i, j}\right)$

where $\tau_{x}$ is the $\mathrm{x}$-direction transmissivity $\left(\mathrm{m}^{2} / \mathrm{s}\right)$ for a lateral flux between node $(\mathrm{i}, \mathrm{j})$ and node $(\mathrm{i}+1, \mathrm{j}), \tau_{z}$ is the $\mathrm{z}$-direction transmissivity $\left(\mathrm{m}^{2} / \mathrm{s}\right)$ applying to a vertical flux between node (i,j) and underlying node (i,j-1), and $\Phi$ is the hydraulic potential ( $m$ ) corresponding to the sum of pressure and matrix potential and gravitational potential. 


\subsection{Porosity}

In BASIN2, the porosity is modeled according to the relation,

$$
\phi=\phi_{o} \exp \left(-\beta_{\phi} \sigma_{v}^{\prime}\right)+\phi_{1}
$$

where $\phi$ is the porosity corresponding to an effective stress $\sigma_{E}, \phi_{o}$ is the reducible porosity, $\phi_{1}$ is the irreducible porosity remaining during burial, and $\beta_{\phi}$ is the compressibility of the reducible pore volume. The compressibility coefficient $\beta_{\phi}$, controlling the decrease in porosity with burial, is defined as

$$
\beta_{\phi}=-\frac{1}{\left(\phi-\phi_{1}\right)} \frac{\partial \phi}{\partial \sigma_{v}^{\prime}}
$$

where $\frac{\partial \phi}{\partial \sigma_{v}^{\prime}}$ is the porosity variation corresponding to the vertical effective stress variation.

\subsection{Permeability (hydraulic conductivity) and intrinsic permeability}

Darcy's permeability $K$ (hydraulic conductivity) depends on the properties of the porous medium as well as the fluid moving through it. $K$ depends on the size of the 
grains and their subsequent distribution as well as the shape, packing and orientation of the sediment particles. This determines the rate of flow of a fluid through a cross section of a porous mass under a unit hydraulic gradient.

BASIN2 software uses the intrinsic permeability coefficient $k_{i}$, which is a property of the porous medium alone (independent of the fluid properties).

$k_{i}=C \cdot d^{2} \quad\left(m^{2}\right)$

where $C$ is the shape factor and $d$ is the mean pore diameter. Hydraulic conductivity $K(\mathrm{~m} / \mathrm{s})$ can be obtained from the intrinsic permeability $k_{i}\left(\mathrm{~m}^{2}\right)$ using the relation,

$K=k_{i} \cdot\left(\frac{\gamma}{\mu}\right)=k_{i} \cdot\left(\frac{\rho \cdot g}{\mu}\right)$

where, $\gamma$ is the specific unit weight of the fluid $\left(\mathrm{N} / \mathrm{m}^{2}\right), \rho$ the fluid density $\left(\mathrm{g} / \mathrm{cm}^{3}\right)$, $g$ the acceleration due to gravity $\left(9.80665 \mathrm{~m} / \mathrm{s}^{2}\right)$, and $\mu$ the dynamic viscosity of the fluid ( 1 centipoise $=0.01 \mathrm{~g} / \mathrm{cm} \cdot \sec$ at $20^{\circ} \mathrm{C}$ ). Therefore, Darcy's permeability (or hydraulic conductivity) depends on the density and viscosity of the fluid. In BASIN2, the 
intrinsic permeability $k_{i}$ (z-direction) is calculated from porosity using the relationship,

$\log k_{i-z}=A \cdot \phi+B$

where, $\phi$ is the porosity, and $A$ and $B$ are constants depending on sediment characteristics.

\subsection{Modeling parameters}

\subsubsection{Porosity versus depth}

We estimated the parameters for the BASIN 2 porosity modeling using the previous modeling from the SeCo software and the results from boring MD99-2288 as shown in Figure 9. We defined porosity (\%) using the relation,

$$
\phi=13 \cdot \exp \left(-0.17 \sigma_{v}^{\prime}\right)+50
$$

The irreducible porosity $\phi_{1}$ remaining during burial was estimated at $50 \%$ from the water content value observed at the borehole 6404/5-GB1, east of the Helland Hansen area $(\mathrm{W}=38.5 \%$; OCR $=1.2$; a depth of $65 \mathrm{~m})$ (NGI 1998). A lower water content 
value, observed at borehole 6405/2, was not used because of its high OCR value $(\mathrm{OCR}=1.8)$.

\subsubsection{Permeability versus depth}

It is widely recognized that permeability varies according to the measured scale (sample or field) and thus, permeability values obtained from oedometer tests might initiate uncertainty in the porosity profile. The permeability distribution with depth was modeled to fit both the profile used with the other model ( $\mathrm{SeCo}$ ) and the values from the oedometer tests (boring MD99-2288; Figure 10). This permeability was compared with two other profiles obtained from boreholes 6404/5 (NGI recommended K-profile in horizontal and vertical directions for in-situ conditions) and 6405/2 (NGI 1998).

To obtain $k_{i}$ from $K$, one uses

$K(\mathrm{~m} / \mathrm{s})=1.08 \cdot 10^{-7} k_{i}\left(\mathrm{~m}^{2}\right)$

and 
$k_{i}\left(m^{2}\right)=1.01316 \cdot 10^{12} K_{i}($ Darcy $)$

Thus, a permeability of $1.0 \cdot 10^{-9}(\mathrm{~m} / \mathrm{s})$ corresponds approximately to $1.0 \cdot 10^{-5}$ Darcy in standard conditions $\left(20^{\circ} \mathrm{C}\right.$, freshwater $)$. For seawater and $6^{\circ} \mathrm{C}$, this corresponds to $1.6 \cdot 10^{-5}$ Darcy

We estimated the permeability profile from porosity, for use in the BASIN2 modeling, using one of the following relations

$\log k_{i-z}=1.91 \cdot(\phi / 100)-5.67$

with $k_{i-z}$ (Darcy),

or

$\log k_{i-z}=1.91 \cdot(\phi / 100)-17.67$

with $k_{i-z}\left(m^{2}\right)$.

As mentioned by NGI (1998), the permeability profile was corrected for in-situ temperature. Intrinsic permeability was estimated using a fluid temperature of $6^{\circ} \mathrm{C}$, based on measurements performed at borehole $6405 / 2-\mathrm{GB} 1 / 1 \mathrm{~A} / 1 \mathrm{~B}\left(5-7^{\circ} \mathrm{C}\right.$ at a depth of between 0 and $60 \mathrm{~m}$ below the seabed). The same fluid temperature $\left(6^{\circ} \mathrm{C}\right)$ was used in our BASIN2 modeling. We also assume similar values of permeability in the horizontal and vertical directions, as recommended by NGI (1998). However, clays 
commonly show an anisotropic ratio for permeability between 1 and 10 .

\subsection{Excess Pore Pressure, 1-D Modeling}

We modeled vertical flow only (1-D) to compare the results with the SeCo modeling. Deposition was simulated starting at $221 \mathrm{kyr}$ BP to create a $100 \mathrm{~m}$ thick layer before the high sedimentation rate period begins. Depth profiles of EPP generation modeled at the end of the maximum sedimentation rate period (15 kyr BP), using BASIN2 and SeCo, agree well (170-180 $\mathrm{kPa}$ at a depth of $80 \mathrm{~m}$ ) (Figure 11). However, 1-D modeling of EPP dissipation does not provide similar results (Figure 11); EPP at $8 \mathrm{kyr}$ BP depends on the software used (higher dissipation modeled with BASIN2 software). The use of two different porosity profiles in the different software may cause the variability observed in the dissipation modeling.

\section{VALIDATION OF THE COMPACTION MODELING}

To examine the validity of the modeling exercise, we compared the outputs for the two software packages. For both, we used a common sedimentation rate of $1 \mathrm{~m} / \mathrm{kyr}$ and then compared the permeability, $(\mathrm{K})$ and unit weight depth profiles obtained by modeling (SeCo and BASIN2) using the field measurements from MD99-2288 
(Figures 12 and 13). Permeability modeling using BASIN2 and SeCo software yields results which are mutually compatible and fit well with the field data (Fig. 11). Results from modeling unit weight profiles depend on the software used $\left(1 \mathrm{kN} / \mathrm{m}^{3}\right.$ difference), and vary according to the distinct permeability profile with depth resulting from each model (Fig. 12).

\section{SHANSEP MODELING}

The following SHANSEP relation (Ladd and Foott 1974) was used to estimate the undrained shear strength $(\mathrm{Su})$ distribution with depth at 15 and 8 kyr BP (Fig. 14) corresponding to the effective stress profile related to EPP generation in the sediment:

$$
S_{u}=\alpha \cdot\left(\sigma_{v}^{\prime}-\Delta u\right) \cdot O C R^{m}
$$

where $S_{u}$ is the undrained shear strength, $\sigma_{v}^{\prime}$ is the vertical effective stress, $\Delta u$ is the excess pore pressure, OCR is the overconsolidation ratio, $\alpha$ is the ratio of undrained shear strength to vertical effective stress for normally consolidated clay (typical values: $0.20-0.25$ ), and $m$ is a dimensionless exponent (typical values: $m=0.75-$ 0.95). Because $\mathrm{OCR}=1$ during the consolidation process (the maximum historical 
stress is always equal to the current stress), we obtain

$$
S_{u}=\alpha \cdot\left(\sigma_{v}^{\prime}-\Delta u\right)
$$

which implies that $S_{u}$ depends strongly on the EPP dissipation. Figure 14 shows that undrained shear strength modeled at $8 \mathrm{kyr} \mathrm{BP}$ is still below values in the present profile $(\mathrm{Su}=50 \mathrm{kPa}$ at a depth of $55 \mathrm{~m}$, instead of $50 \mathrm{kPa}$ at a depth of $30 \mathrm{~m}$ for the present day profile).

\section{SLOPE STABILITY}

Using the SHANSEP model and the simulated vertical effective stress distribution during the consolidation process, we estimated the pseudo-static safety factor $(0.175 \mathrm{~g}$ pseudo-static acceleration for 0.35g PGA from NORSAR 1998) using an infinite slope analysis ( $1^{\circ}$ slope angle) (Figure 15). The factor-of-safety, F, is defined as the shear strength divided by the mobilized shear stress; for an infinite slope this is

$$
F=\frac{s_{u}}{\left(\gamma^{\prime} \cdot z \cdot \sin \lambda \cdot \cos \lambda\right)+\left(K_{X} \cdot \gamma \cdot z \cdot \cos ^{2} \lambda\right)}
$$


where $S_{u}$ is the undrained shear strength at the given depth $z, \lambda$ is the slope angle, $\gamma$ is the effective unit weight of the sediment, $\gamma$ is the total unit weight of the sediment, and $K_{X}$ is the pseudo-static seismic acceleration in $\mathrm{g}(0.1$ means $10 \%$ of gravity acceleration). In the high sedimentation rate area at $8 \mathrm{kyr} \mathrm{BP}$, the safety factor is below unity (unstable infinite slope) down to a depth of $60 \mathrm{~m}$ (Figure 15).

\section{2-D MODEL WITH SLOPE ANGLE (BASIN2 software)}

We consider now a 2-D model with the same sediment parameters as the 1-D analyses described previously, but including a layer with a higher permeability (or hydraulic conductivity: $5.0 \cdot 10^{-10} \mathrm{~m} / \mathrm{s}$ ) and higher water content as shown in borehole 6404/5 (Figure 16; a depth of between 123 and 152 m) (NGI 1998). Calculations of EPP generation and dissipation in the sediment are similar for both 1-D and 2-D models, assuming a uniform sedimentation rate. However, sedimentation rate can vary laterally over the slide area. Therefore we modeled a $15 \mathrm{~km}$ long continental slope $\left(1^{\circ}\right.$ slope angle) with a high sedimentation rate (16.2-15.0 kyr BP) over the first $5 \mathrm{~km}$, the rate decreasing linearly from $5 \mathrm{~km}$ (maximum rate) to $10 \mathrm{~km}$ (nearly zero) and continuing at this low rate from $10 \mathrm{~km}$ to the end of the model $(15 \mathrm{~km})$ (Figure 17). This modeling was performed to understand the lateral pore pressure dissipation process during the period $15 \mathrm{kyr} \mathrm{BP}-8 \mathrm{kyr} \mathrm{BP}$ in the vicinity of the rapid sedimentation area. 
At the end of the rapid sedimentation (15 kyr BP), modeled overpressure reaches a maximum of $200 \mathrm{kPa}$, with approximately $160 \mathrm{kPa}$ at a depth of $75 \mathrm{~m}$ and $180 \mathrm{kPa}$ at a depth of $100 \mathrm{~m}$ (Figure 17). On the right side of the model (10-15 km distance), the sedimentation rate is close to zero for the period $16.2-15.0 \mathrm{kyr}$ BP $(0.5 \mathrm{~m} / \mathrm{kyr})$. However, an overpressure of $20 \mathrm{kPa}$ is apparent at a depth of 60-70 m at $15 \mathrm{kyr} \mathrm{BP}$.

Between $15 \mathrm{kyr}$ BP and 8 kyr BP the EPP migrates downslope from the area of high sedimentation towards the area where sedimentation rate is low. Dissipation in the $\mathrm{x}$-direction is easier due to the higher permeability associated with the high porosity layer. At $8 \mathrm{kyr} \mathrm{BP}$, the excesss pore pressure is estimated between 10 and 20 $\mathrm{kPa}$ at a depth of $100 \mathrm{~m}$ for the $15 \mathrm{~km}$ distance (Figure 18).

Given an anisotropy in permeability (similar $k_{i-x}$ but lower $k_{i-z}$ ) above the high permeability layer, upward dissipation there is lower and a more pronounced EPP was simulated at $8 \mathrm{kyr} \mathrm{BP}$ in the right side of the model (above $20 \mathrm{kPa}$ at a depth of $100 \mathrm{~m}$ at $15 \mathrm{~km}$ distance) (Figure 19). Thus, the maximum fluid overpressure is lower at $8 \mathrm{kyr} \mathrm{BP}$ than at $15 \mathrm{kyr} \mathrm{BP}(15 \mathrm{kyr} \mathrm{BP}$ is the end of the rapid sedimentation period), but the area of deep sediments impacted by EPP is larger due to the lateral extension of pore pressure. This could partially explain why no large failure has been observed before $8 \mathrm{kyr}$. Sediment permeability might well be locally lower due to the presence of gas in the pores or dissolved gas in water reducing the fluid viscosity. This would slow down the EPP dissipation and thus retard the shear strength increase with time in the 
sediment.

\section{DISCUSSION}

The 1-D EPP dissipation modeling results from both software packages provides different results at $8 \mathrm{kyr}$ BP. This might be explained by the difference in the porosity profiles (and thus permeability) in the upper $15 \mathrm{~m}$.

One of the main parameters controlling the modeling results (EPP generation and dissipation) is the permeability distribution in the sediment. This distribution depends on time and depth. A permeability profile more representative of the period corresponding to the high sedimentation rate (Late Weichselian) that provides higher permeability values for the upper sediment column would most likely simulate a lower EPP generation in the sediment column. However, our approach considers the critical effects of the development of low permeability in the sediment based on available permeability measurements. The values we used are in the range of observed values. Furthermore, some layers deposited before the Late Weichselian in the Storegga slide area and affected by the EPP generation exhibit a low permeability values (borehole 6404/5). This suggests that they might act as a barrier to upward water fluxes. Thus, if the modeling overestimates EPP generation in the sediment during subsurface consolidation, it does not do so for the already consolidated underlying layers. An 
important aspect of the results seems to be the lateral extent of EPP dissipation with the degree of maximum EPP generation which are closely related to uncertainties existing in the input parameters. The piezometer installed at site 22 (central region) recorded EPP around $140 \mathrm{kPa}$ at a depth of $95 \mathrm{~m}$, corresponding to a $15 \%$ excess hydrostatic pore pressure, whereas pore pressure measured in the northern flank for a depth range of 15.6 and $28 \mathrm{~m}$ indicates hydrostatic pressure conditions (Strout \& Tjelta 2005) (Table 5 \& Figure 20). These findings suggest that EPP generation might have been higher in the central part of the Storegga slide (Ormen Lange) compared to the northern flank.

The pseudo-static approach to modeling the infinite slope stability under earthquake loading is limited. The acceleration force brings the sediment to failure during fractions of a second and results in very limited shear strains developing and accumulating during the earthquake. Therefore, the use of the pseudo-static safety factor below unity as a failure threshold is not recommended even though the pseudostatic acceleration used in the modeling corresponds to only one half of the expected peak ground acceleration in the area. This approach is considered more as a reference tool to measure the degree of the EPP effects than as an explanation for the Storegga slide, which possibly involved a much more complex rupture process (requiring analysis using non-linear dynamics).

Excess pore pressure resulting from rapid sedimentation can play a major role 
in the stability of gentle slopes depending on a few sediment parameters. This process can occur in sediment recently accumulated (by rapid sedimentation), and thus preventing consolidation, but it can also occur in sediment deposited before rapid sedimentation and already (partially or completely) consolidated. One also has to consider sediment affected only by the lateral EPP dissipation (Figure 21). In this case, the EPP drastically modifies the stress state in the sediment, thereby reducing the vertical effective stress which might also play a significant role in the large scale lateral instability process.

\section{CONCLUSIONS}

In the Helland Hansen area on the mid-Norwegian margin, the excess pore pressure generated in the sediment at the end of the high sedimentation rate phase (c. $15 \mathrm{kyr}$ BP) is estimated at roughly $33 \%$ of the initial vertical effective stress (2-D BASIN2 model; $170-180 \mathrm{kPa}$ at a depth of $80 \mathrm{~m}$ ). This means that rapid sedimentation can significantly affect the vertical effective stress and thus the slope stability.

According to the modeling, the dissipation of excess pore pressure is incomplete at 8 kyr BP (dissipation during $7 \mathrm{kyr}$ ) and remains significant at the 100-m depth (2-D BASIN2 model) suggesting a likely delayed action on slope stability. Note however 
that the excess pore pressure modeling is very sensitive to both the input permeability and the compressibility profile used for saturated sediments. This adds considerable uncertainty to the results.

The slope stability assessment at $8 \mathrm{kyr}$ BP (back-analysis) takes into account an incomplete consolidation and shows an unstable slope down to a depth of $60 \mathrm{~m}$ with a $0.175 \mathrm{~g}$ pseudo-static seismic acceleration. Still unresolved is why the slope remained stable during $7 \mathrm{kyr}$ (from $15 \mathrm{kyr}$ BP to $8 \mathrm{kyr} \mathrm{BP}$ ) when a very low undrained shear strength in the high sedimentation rate area prevailed.

Given a variable heterogeneous lateral sedimentation rate and a layer having a high permeability coefficient at a depth of $80 \mathrm{~m}$ with an anisotropy in permeability $\left(K_{x} / K_{z}=5\right.$ ) considered below and above, simulations using BASIN2 software show a more pronounced downslope migration of excess pore pressure in the sediment between $15 \mathrm{kyr} \mathrm{BP}$ and $8 \mathrm{kyr} \mathrm{BP}$. The maximum excess pore pressure ratio at $8 \mathrm{kyr} \mathrm{BP}$ is around $15 \%$ of vertical effective stress in the high sedimentation rate area $(0-5 \mathrm{~km}$; $60-\mathrm{m}$ depth) and around $10 \%$ in the low $(0.5 \mathrm{~m} / \mathrm{kyr})$ sedimentation rate area $(10-15$ km; 60-m depth). This illustrates how excess pore pressure could migrate beneath layers and affect larger areas over a 7000 year period, favoring large scale instability. 
The simulation results show that, under certain conditions, excess pore pressure resulting from rapid sedimentation causing overloading can be sufficient to favor or provoke widespread instability of very gentle slopes in the deep subsurface (110 m or even more). This has to be considered for slope stability assessment in areas where rapid sedimentation has occurred.

\section{ACKNOWLEDGEMENTS}

This work is a contribution to the COSTA European project under contract EVK31999-00028. We would like to thank Berit O. Hjelstuen for providing a complete set of figures in the Helland Hansen area and Daniel O. Hayba from the USGS for his support in the use of BASIN2 software. Thanks to Manon Wilken for digitizing slide areas outlines off the Norwegian margin, to T. J. Kvalstad (NGI) for a preliminary review which distinctly improved an earlier version of the manuscript and to Geoff Corner, Maarten Vanneste and Dr. Roy Sidle for improving the manuscript at a final stage.

\section{REFERENCES}

Adams JRCE, Roberts HH (1993) A Model of effects of sedimentation rate on stability of the Mississippi Delta sediments. Geo-Marine Letters 21: 1-7.

Baraza J, Lee HJ, Kayen R, Hampton MA (1990) Geotechnical characteristics and slope stability on the Ebro margin, western Mediterranean. Marine Geology 95: 379393.

Bethke CM, Lee MK, Park J (2002) Basin Modeling with Basin2: A guide to using Basin2 software package; University of Illinois, $210 \mathrm{p}$ 
Bryn P, Berg K, Lien R, Solheim A, Ottesen D, Rise L (2002) The Storegga geomodel and its use in slide risk evaluation: Geological and Geotechnical site investigation in the Storegga slide area. Offshore Site Investigation and Geotechnics; Proceedings International Conference, London UK.

Bryn P, Kvalstad TJ, Guttormsen TR, Kjaernes PA, Lund JK, Nadim F, Olsen J (2004) Storegga slide risk assessment. Offshore Technology Conference, Houston, Texas, 3-6 May, OTC 16580, 14 p

Bryn P, Berg K, Forsberg CF, Solheim A, Kvalstad TJ (2005) Explaining the Storegga Slide. Marine and Petroleum Geology, 22 (1-2): 11-19.

Bünz S, Mienert J (2004) Acoustic imaging of gas hydrate and free gas at the Storegga Slide. Journal of Geophysical Research-Solid Earth, 109(B4), B04102, doi:04110.01029/02003JB002863.

Gibson RE (1958) The progress of consolidation in a clay layer increasing in thickness with time, Geotechnique 8: 171-182.

Haflidason H, Sejrup HP, Bryn P, Lien R (2001) The Storegga slide: chronology and flow mechanism, paper presented at the XI European Union of Geoscientists meeting, 8-12 April, Strasbourg, France.

Haflidason H, Sejrup HP, Nygård A, Mienert J, Bryn P, Lien R, Forsberg CF, Berg K, Masson D (2004) The Storegga slide: Architecture, geometry and slide development, Marine Geology 213 (1-4): 201-234.

Haflidason H, Lien R, Sejrup HP, Forsberg CF, Bryn P (2005) The dating and morphometry of the Storegga slide, Marine and Petroleum Geology 22 (1-2): 123-136.

Hjelstuen BO, Sejrup HP, Haflidason H, Nygård A, Berstad IM, Knorr G (2004) Late Quaternary seismic stratigraphy and geological development of the south Vøring margin, mid-Norway, Quaternary Science Reviews 23: 1847-1865.

Huene R. v, Ranero CR, Watts P (2001) Instability and Tsunamigenic Potential at Convergent Margins, Eos Trans. AGU, 82(47), Fall Meet. Suppl., Abstract H22G-04.

Kvalstad TJ, Gauer P, Kayina AM, Nadim F, Bryn, P (2002) Slope stability at Ormen Lange. Offshore Site Investigation and Geotechnics; Proceedings International 
Conference, London UK.

Kvalstad TJ, Andresen L, Forsberg CF, Berg K, Bryn P, Wangen M (2005a) The Storegga Slide: Evaluation of triggering sources and slide mechanics. Marine and Petroleum Geology 22 (1-2): 245-256.

Kvalstad TJ, Nadim F, Kaynia AM, Mokkelbost KH, Bryn P (2005b) Soil conditions and slope stability in the Ormen Lange area. Marine and Petroleum Geology 22 (1-2): 299-310.

Laberg JS, Vorren TO, Mienert J, Haflidason H, Bryn P, Lien R (2003) Preconditions leading to the Holocene Trænadjupet Slide offshore Norway. In: Submarine Mass Movements and their consequences, J. Locat \& J. Mienert (editors), pp 247-257.

Ladd CC, Foott R (1974) New design procedure for stability of soft clays. Proceedings of ASCE, GT7: 763-786.

Leynaud D, Mienert J, Nadim F (2004) Slope stability assessment of the Helland Hansen area offshore the Mid-Norwegian margin, Marine Geology 213 (1-4): 457480 .

Lindberg B, Laberg JS, Vorren TO (2004) The Nyk Slide-morphology, progression, and age of a partly buried submarine slide offshore northern Norway. Marine Geology 213 (1-4): 277-289.

NORSAR (1998) Development of a seismic zonation for Norway. Norwegian council for Building Standardization (NBR).

Norwegian Geotechnical Institute (NGI) (2000) Ormen Lange, Long Sample MD99 2288, Report N. 992527-1, Oslo, Norway.

Norwegian Geotechnical Institute (NGI) (1998) Møre and Vøring soil investigation 1997, vol. I and II. Report No. 972521-1, Oslo, Norway.

Solheim A, Berg K, Forsberg CF, Bryn P (2005) The Storegga Slide complex: Repetitive large scale sliding with similar cause and development. Marine and Petroleum Geology 22 (1-2): 97-107.

Strout JM, Tjelta TI (2005) In situ pore pressures: What is their significance and how can they reliably measured? Marine and Petroleum Geology 22 (1-2): 275-285. 
Sultan N, Cochonat P, Canals M, Cattaneo A, Dennielou B, Haflidason H, Laberg JS, Long D, Mienert J, Trincardi F, Urgeles R, Vorren TO, Wilson C (2004) Triggering mechanisms of slope instability processes and sediment failures on continental margins: A geotechnical approach. Marine Geology Special Issue (COSTA) 213 (1-4): 291-321.

Terzaghi K, Peck RB (1967) Soil Mechanics in Engineering Practice, Second Edition, John Wiley \& Sons, Inc., 729 p

Tjelta T, Strout J, Solheim A, Mokkelbost KH, Berg K, Bryn P (2002) Ormen Lange geoborings - Geological and Geotechnical site investigations in the Storegga slide area. Offshore Site Investigation and Geotechnics; Proceedings of International Conference, London UK. 


\section{Figures and Tables captions}

Figure 1: Location of the Storegga slide area (red), Traenadjupet (Tr) and Bjornoyrena (Bj) slides and location of Figure 20 (black rectangle).

Figure 2: Sketch showing the main slip planes (TNS, TNR and INO3) of the Storegga slide (Bryn et al. 2002).

Figure 3: Maximum sedimentation rates around the MD-2291 core site (from Hjelstuen et al. 2004).

Figure 4: Location of MD99-2291 and MD99-2289 (MD99-2288) cores and areas of rapid sedimentation deduced from seismic horizons (from Hjelstuen et al. 2004) with the location of the main ice streams interpreted to have existed in the vicinity of the Storegga slide (from Bryn et al. 2002). $\mathrm{BD}=$ Buadjupet; $\mathrm{SD}=$ Sklinnadjupet.

Figure 5: Comparison of SeCo software numerical solutions with analytical solutions from Gibson (1958); EPP (initial vertical effective stress ratio) versus normalized depth for different values of $\frac{S R_{\text {Gibson }}}{2 \cdot \sqrt{C_{V}}}$, where $S R_{\text {Gibson }}$ is the sedimentation rate for $t^{\frac{1}{2}}$ (square root of time $t$ ) and $C_{V}$ the coefficient of consolidation.

Figure 6: $\log (\mathrm{K})$ versus void ratio estimated from oedometer tests (boring MD99-2288). White circles correspond to values not used for estimating linear trend.

Figure 7: Compressibility index data with depth; the average value $(\lambda=0.205$, black line $)$ with $+/$ - one standard deviation (dotted lines).

Figure 8: Excess pore pressure generation estimated at $15 \mathrm{kyr} \mathrm{BP}$ and $8 \mathrm{kyr} \mathrm{BP}$ from 1-D simulation using the highest sedimentation rate estimated by Hjelstuen et al. (2004). $(\lambda=0.18)$.

Figure 9: Porosity profiles used in SeCo and BASIN2 modeling compared to the values observed in boring MD99-2288, 6405/2 and 6404/5. The porosity distribution profile used in the software does not fit the $6405 / 2$ porosity curve because the latter corresponds mainly to overconsolidated sediment $(\mathrm{OCR}=1.4$ to1.8).

Figure 10: Permeability profiles used for $\mathrm{SeCo}$ and BASIN2 modeling compared to results from oedometer tests.

Figure 11: Overpressure modeling at $15 \mathrm{kyr}$ BP and 8 kyr BP using SeCo and BASIN2 softwares. 
Sedimentation rate and permeability in slope stability

Figure 12: Permeability versus depth obtained from simulation (SeCo: full line; BASIN2: dotted line) compared to measurements on boring MD99-2288 (black dots) and NGI recommended profile for borehole 6404/5.

Figure 13: Unit weight versus depth obtained from simulations (SeCo: full black line; BASIN2: dotted line) compared to measurements on boring MD99-2288 (black dots) and recommended K-profile for borehole 6404/5 (red line).

Figure 14: a) Vertical effective stress profiles versus depth estimated at $15 \mathrm{kyr}$ BP, $8 \mathrm{kyr}$ BP and for the present-day resulting from the consolidation process (BASIN2) and b) the corresponding Su profiles versus depth according to SHANSEP. Su values increase during consolidation. The critical effective stress value is considered at $8 \mathrm{kyr} \mathrm{BP}$.

Figure 15: Pseudo-static safety factor estimated using infinite slope analysis; Pseudo-static acceleration=0.175 g (max PGA=0.35g for 10000 year return period, NORSAR 1998); slope angle of 1 degree.

Figure 16: Permeability (hydraulic conductivity; recommended k-profile, corrected for in-situ conditions) and water content (average values) profiles for borehole 6404/5.

Figure 17: Modeled 2-D EPP at $15 \mathrm{kyr}$ BP with a slope angle of 1 degree. Layer from 123 to $152 \mathrm{~m}$ depth with higher porosity ( $68 \%$ max decreasing to $55 \% \mathrm{~min})$ and higher permeability $\left(5.0 \cdot 10^{-10} \mathrm{~m} / \mathrm{s}\right.$ instead of $1.2 \cdot 10^{-10} \mathrm{~m} / \mathrm{s}$ ). No anisotropy in permeability. The EPP ratio is around $40 \%$ of vertical effective stress at 60-m depth below the high sedimentation rate (HSR; black arrows) area.

Figure 18: Modeled 2-D EPP at $8 \mathrm{kyr}$ BP with a slope angle of 1 degree. Layer with higher water content and higher permeability. Full flow ( $\mathrm{x}$ - and $\mathrm{y}$ - directions drainage). The EPP ratio is still around $15 \%$ of the initial vertical effective stress at a depth of $60 \mathrm{~m}$ below the high sedimentation rate area and around $10 \%$ at a similar depth but in an area not affected by rapid sedimentation (between 10 and $15 \mathrm{~km}$ distance).

Figure 19: Modeled 2-D EPP dissipation at $8 \mathrm{kyr}$ BP; high permeability layer $\left(\mathrm{K}=5.0 \cdot 10^{-10} \mathrm{~m} / \mathrm{s}\right)$ between 2 low $K_{y}$ permeability layers (anisotropy $K_{x} / K_{y}=5$ ). Full flow (x- and y- directions), 1 degree slope angle.

Figure 20: Site locations in the Storegga slide area with estimated excess pore pressure. The location of the area is shown on Figure 1.

Figure 21: The three main levels of overpressure in the sediment; 1) overpressure generated in the rapidly deposited sediment; 2) overpressure generated in the normally deposited sediment; 3) overpressure propagating laterally due to the presence of a low permeability layer (red line). 


\begin{tabular}{|c|c|c|c|c|c|}
\hline & $\begin{array}{c}\text { Moisture } \\
\text { content }\end{array}$ & $\begin{array}{c}\text { Clay } \\
\text { fraction }\end{array}$ & Sand fraction & Plasticity & $\begin{array}{c}\text { Triaxial test } \\
\text { compression }\end{array}$ \\
\hline $\begin{array}{c}\text { Glacial } \\
\text { deposits }\end{array}$ & $<20 \%$ & 28 to $35 \%$ & 5 to $15 \%$ & medium to low & $\begin{array}{c}\text { dilative } \\
\text { behavior }\end{array}$ \\
\hline $\begin{array}{c}\text { Marine } \\
\text { deposits }\end{array}$ & $>30 \%$ & $>45 \%$ & Very little & medium to high & $\begin{array}{c}\text { contractive } \\
\text { behavior }\end{array}$ \\
\hline
\end{tabular}

Table 1: Characteristics of the two main sediment types in the Storegga slide area 


\begin{tabular}{|c|c|c|c|c|c|}
\hline$U_{a v}$ & $\mathbf{T}$ & $\begin{array}{c}m_{w} \\
(\mathbf{1} / \mathbf{m})\end{array}$ & $\begin{array}{c}\text { Consolidation time } \\
(\mathbf{y}) \\
\mathbf{K}=5 \cdot 10^{-10}\end{array}$ & $\begin{array}{c}\text { Consolidation time } \\
(\mathbf{y}) \\
\mathbf{K}=3.0 \cdot 10^{-10}\end{array}$ & $\begin{array}{c}\text { Consolidation time } \\
(\mathbf{y}) \\
\mathbf{K}=1.5 \cdot 10^{-10}\end{array}$ \\
\hline $\mathbf{5 0 \%}$ & $\mathbf{0 . 0 0 8}$ & $10^{-2}$ & $\mathbf{4 5 0}$ & $\mathbf{7 5 0}$ & $\mathbf{1 5 0 0}$ \\
\hline $\mathbf{9 0 \%}$ & $\mathbf{0 . 8 4 8}$ & $10^{-2}$ & $\mathbf{1 9 4 0}$ & $\mathbf{3 2 3 0}$ & $\mathbf{6 4 5 0}$ \\
\hline $\mathbf{5 0 \%}$ & $\mathbf{0 . 0 0 8}$ & $10^{-3}$ & $\mathbf{4 5}$ & $\mathbf{7 5}$ & $\mathbf{1 5 0}$ \\
\hline $\mathbf{9 0 \%}$ & $\mathbf{0 . 8 4 8}$ & $10^{-3}$ & $\mathbf{1 9 4}$ & $\mathbf{3 2 3}$ & $\mathbf{6 4 5}$ \\
\hline
\end{tabular}

Table 2: Time for average consolidation $\left(U_{a v}\right)$ depending on $m_{w}$ and $\mathrm{K}$ for $\mathrm{H}=60 \mathrm{~m}$. 


\begin{tabular}{|c|c|c|c|}
\hline Depth $(\mathrm{m})$ & $\begin{array}{c}W_{i}(\%) \\
\text { (water content) }\end{array}$ & $\begin{array}{c}e_{o} \\
\text { (initial void ratio) }\end{array}$ & $\begin{array}{c}K \\
(\mathrm{~m} / \mathrm{s})\end{array}$ \\
\hline 7.05 & 53.7 & 1.48 & $7.5 \cdot 10^{-10}$ \\
\hline 11.55 & 76.3 & 2.10 & $5.0 \cdot 10^{-10}$ \\
\hline 16.03 & 58.6 & 1.61 & $3.5 \cdot 10^{-10}$ \\
\hline 18.97 & 56.6 & 1.56 & $1.2 \cdot 10^{-9}$ \\
\hline 19.47 & 37.8 & 1.04 & $2.1 \cdot 10^{-10}$ \\
\hline 20.97 & 56.8 & 1.56 & $1.9 \cdot 10^{-10}$ \\
\hline
\end{tabular}

Table 3: Summary of oedemeter tests $\left(\mathrm{ei}=2.75^{*} W_{i}\right)$; Boring MD99-2288. $W_{i}$, water content; $e_{o}$, void ratio; $K$, permeability coefficient. 


\begin{tabular}{|c|c|c|c|c|c|c|c|c|}
\hline $\begin{array}{c}\text { Depth } \\
(\mathrm{m})\end{array}$ & $\begin{array}{c}P_{o}^{\prime} \\
(\mathrm{kPa})\end{array}$ & $\begin{array}{c}W_{i} \\
(\%)\end{array}$ & $e_{o}$ & $\begin{array}{c}\sigma_{v}^{\prime} \\
(\mathrm{kPa})\end{array}$ & $\begin{array}{c}\sigma_{v o}^{\prime} \\
(\mathrm{kPa})\end{array}$ & $\begin{array}{c}\varepsilon_{a} \\
(\%)\end{array}$ & $a$ & $\lambda$ \\
\hline 7.05 & 38.3 & 53.72 & 1.48 & 400 & 12 & 0.25 & 0.071 & 0.177 \\
\hline 11.55 & 67.6 & 76.31 & 2.10 & 700 & 20 & 0.31 & 0.087 & 0.270 \\
\hline 16.03 & 96.7 & 58.56 & 1.61 & 1000 & 40 & 0.27 & 0.084 & 0.219 \\
\hline 18.97 & 116.2 & 56.58 & 1.56 & 1000 & 50 & 0.23 & 0.077 & 0.196 \\
\hline 19.47 & 119.5 & 37.78 & 1.04 & 300 & 50 & 0.115 & 0.064 & 0.131 \\
\hline 20.97 & 127.5 & 56.78 & 1.56 & 1000 & 50 & 0.28 & 0.093 & 0.239 \\
\hline
\end{tabular}

Table 4: $a$ and $\lambda$ parameters obtained from oedometer tests (Boring MD99 2288). $P_{o}^{\prime}$, in-situ vertical effective stress; $W_{i}$, water content; $e_{o}$, void ratio; $\sigma_{v o}^{\prime}$ and $\sigma_{v}^{\prime}$, initial and final vertical effective stresses during consolidation tests; $\varepsilon_{a}$, axial deformation; $\varepsilon_{a}$, compressibility index. 


\begin{tabular}{|c|c|c|c|}
\hline Site & $\begin{array}{c}\text { Filter deph } \\
(\mathbf{m})\end{array}$ & $\begin{array}{c}\text { Estimated } \\
\text { Excess Pore Pressure } \\
(\mathbf{k P a})\end{array}$ & $\begin{array}{c}\text { Estimated } \\
\text { Excess Pore Pressure ratio } \\
(\%)\end{array}$ \\
\hline $19 \_2$ & 230 & 200 & 9 \\
\hline 20 & 65 & 103 & 16 \\
\hline 20 & 72 & -50 & -7 \\
\hline 20 & 9 & 1 & 1 \\
\hline 22 & 95 & 140 & 0 \\
\hline 99 & 180 & 0 & 0 \\
\hline NF\#1 & 15.6 & 0 & 0 \\
\hline NF 5 & 24.4 & 0 & 1 \\
\hline NF P1 & 28 & 3 & 0 \\
\hline NF P3 & 24 & 0 & \\
\hline
\end{tabular}

Table 5: Estimated excess pore pressure from piezometers (Strout \& Tjelta 2005). NF, northern flank. Excess Pore Pressure ratio in \% of hydrostatic. Site locations are shown on Figure 20. 


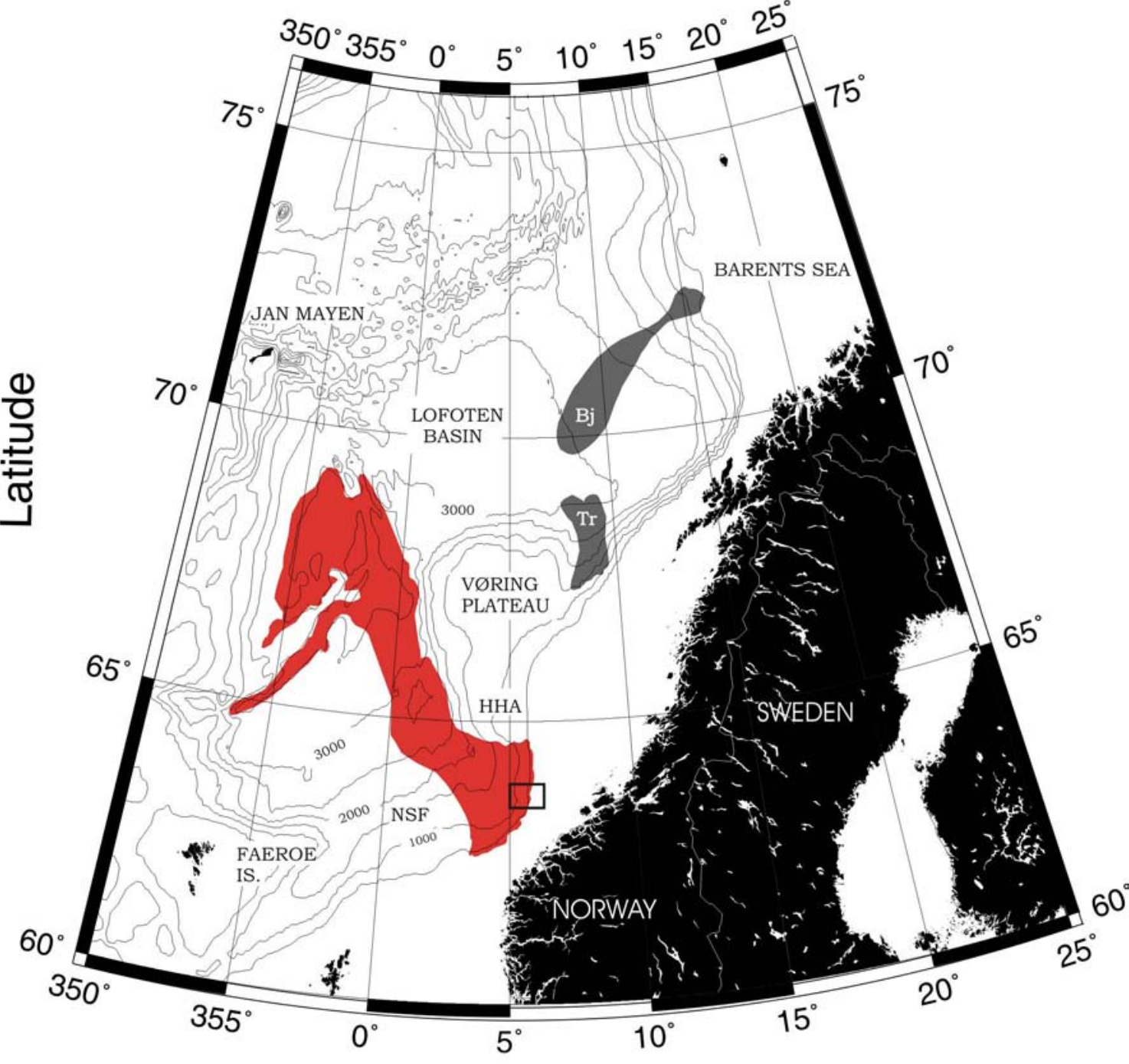


Exposed and polished slip plane

TNS

INO3

TNR 


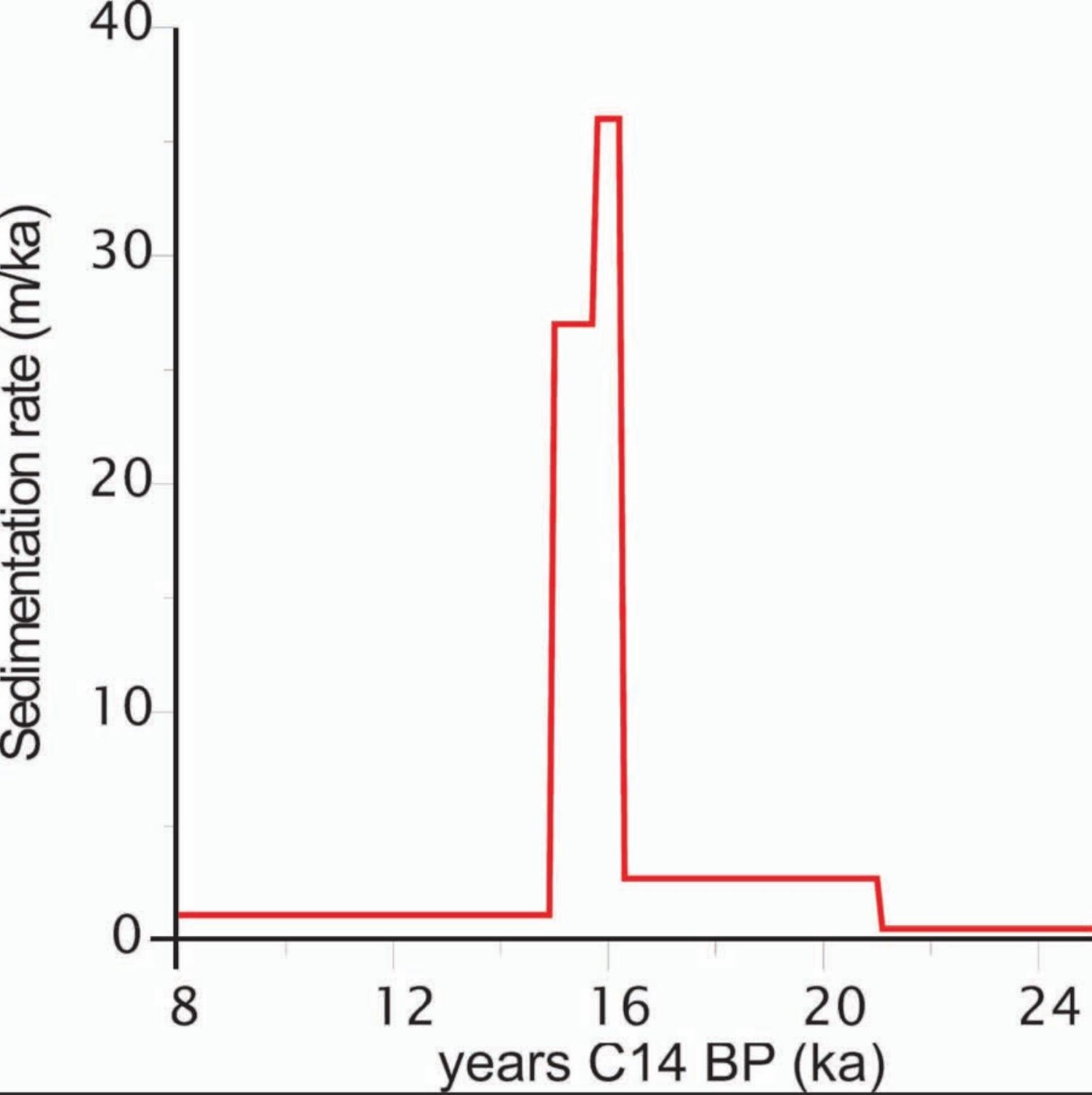




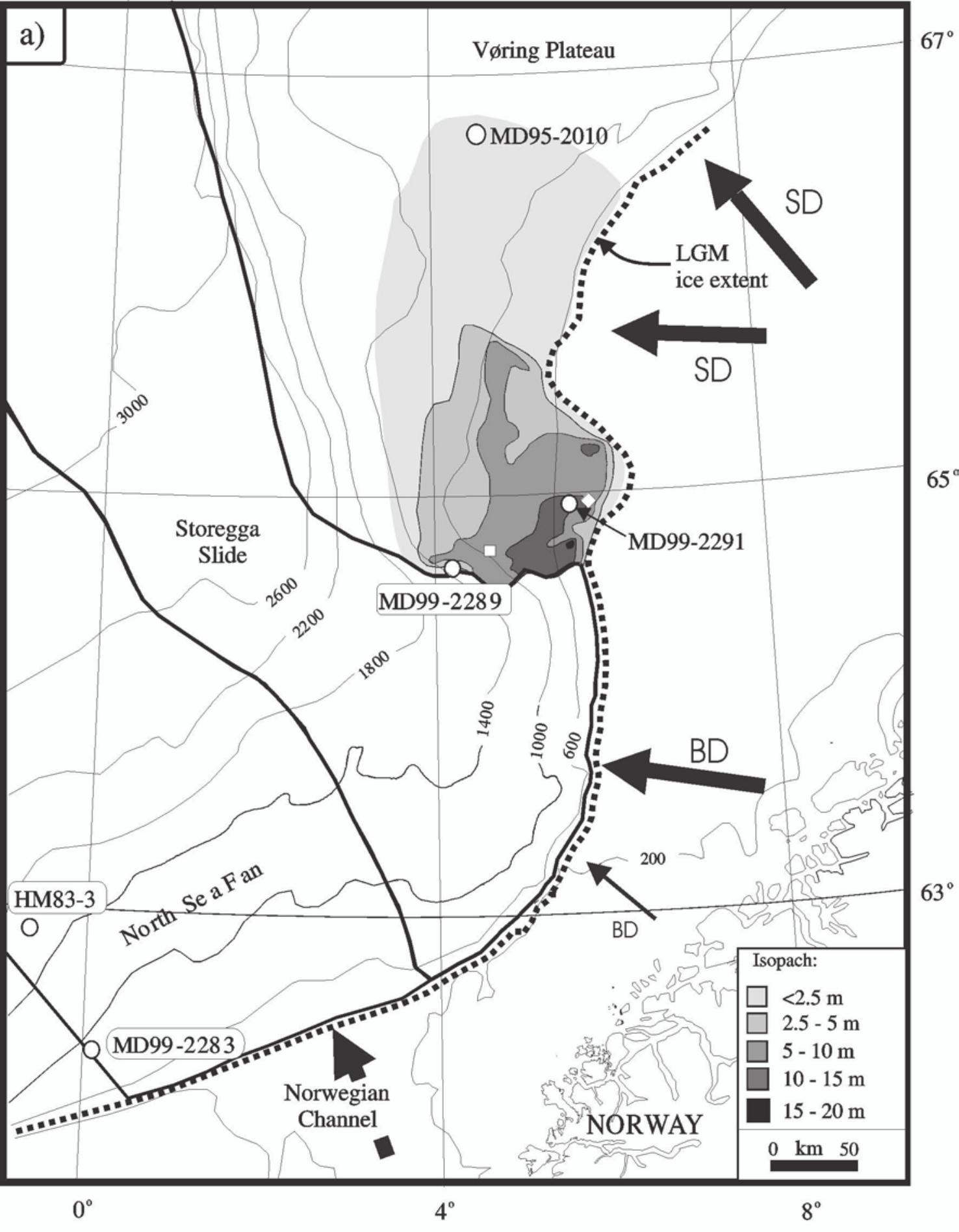




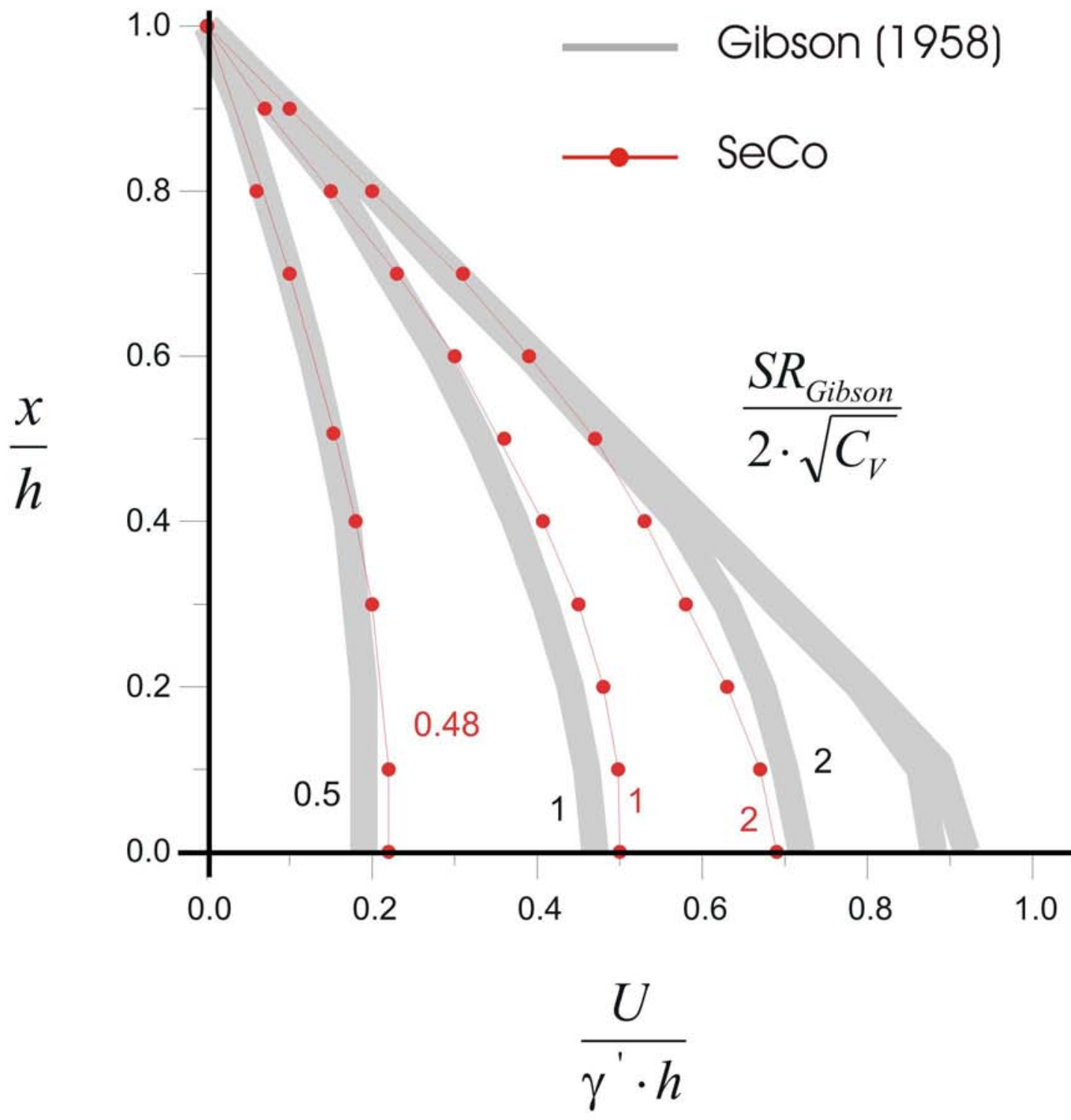




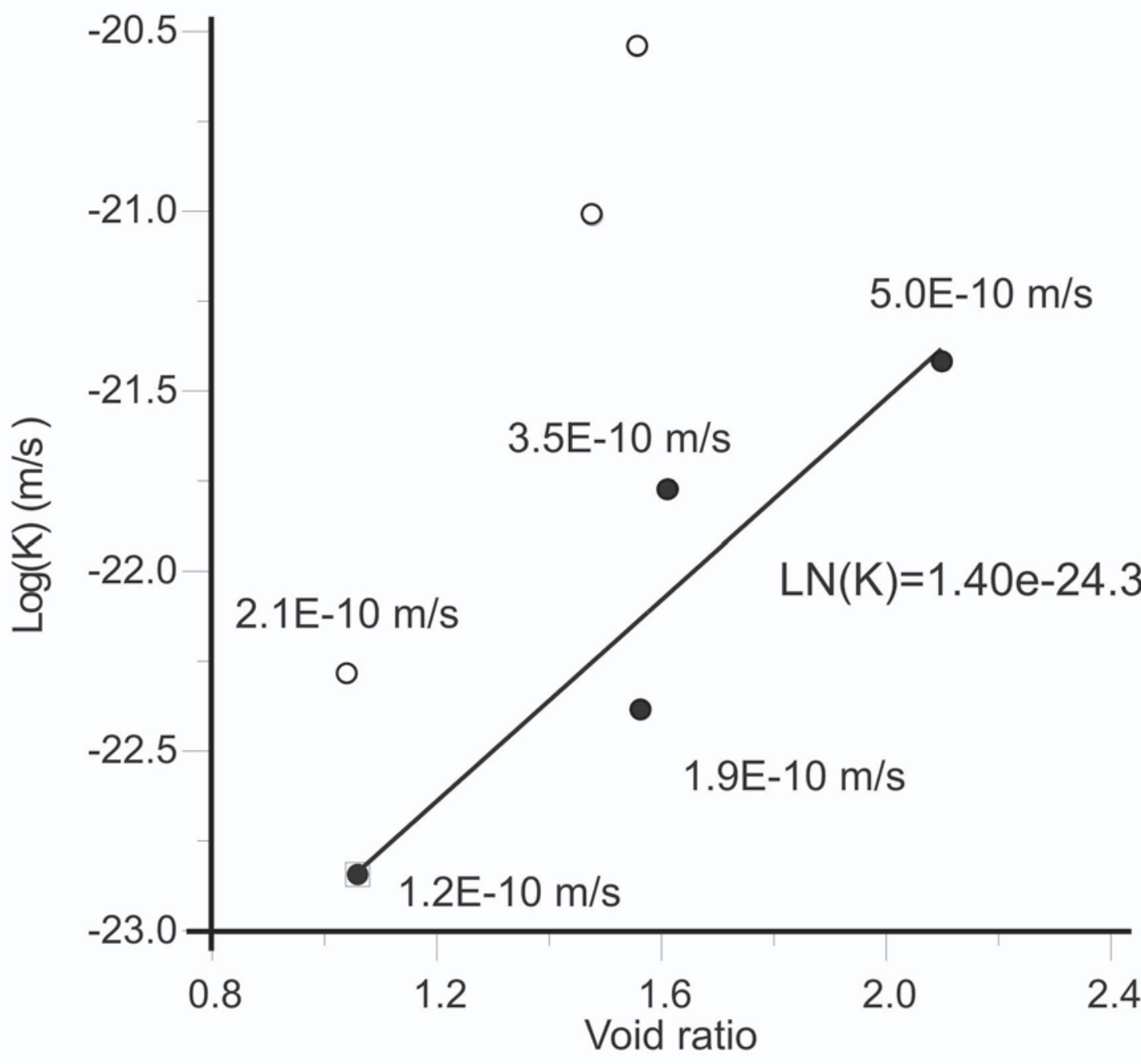


Excess Pore Pressure (kPa)

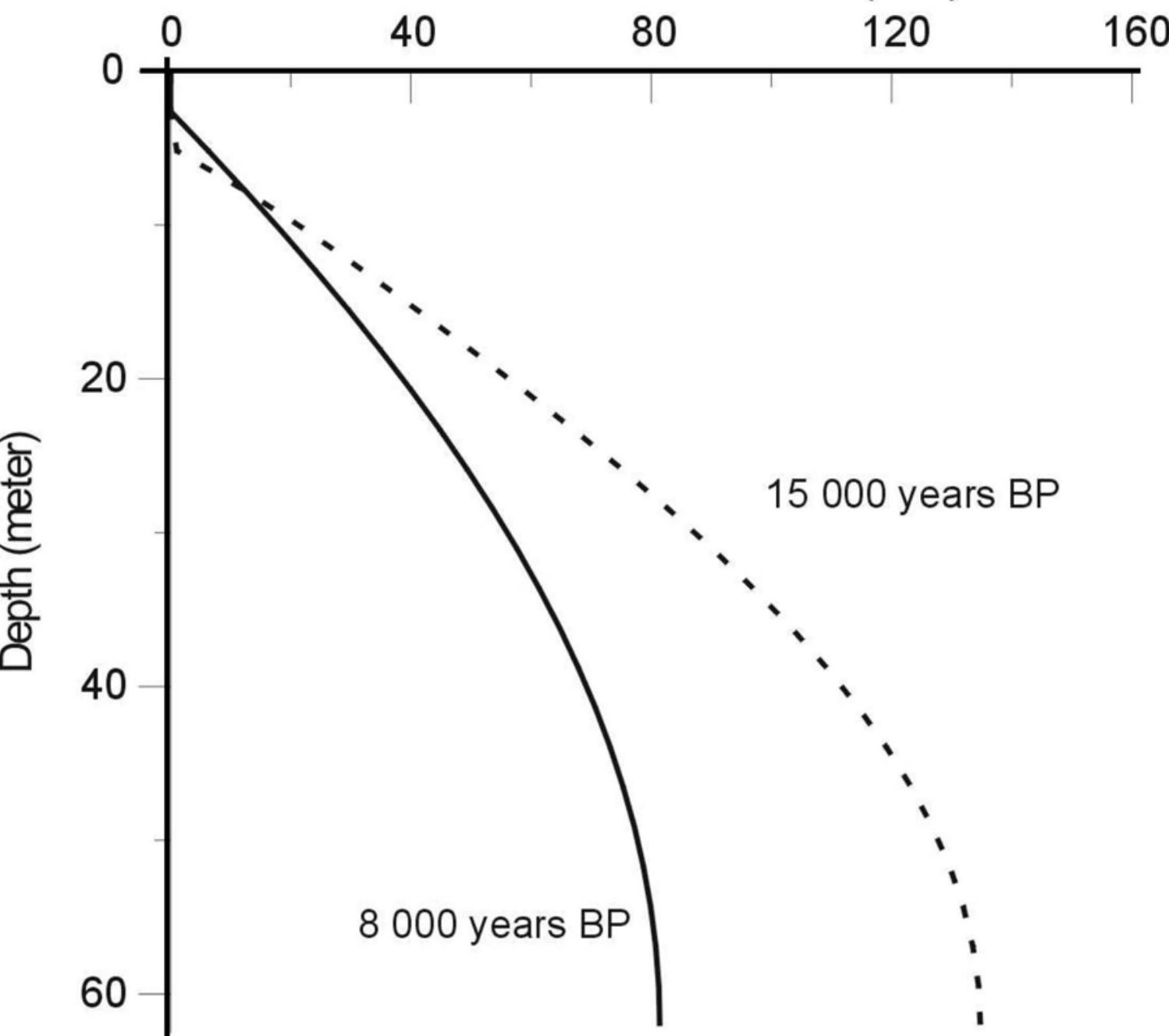




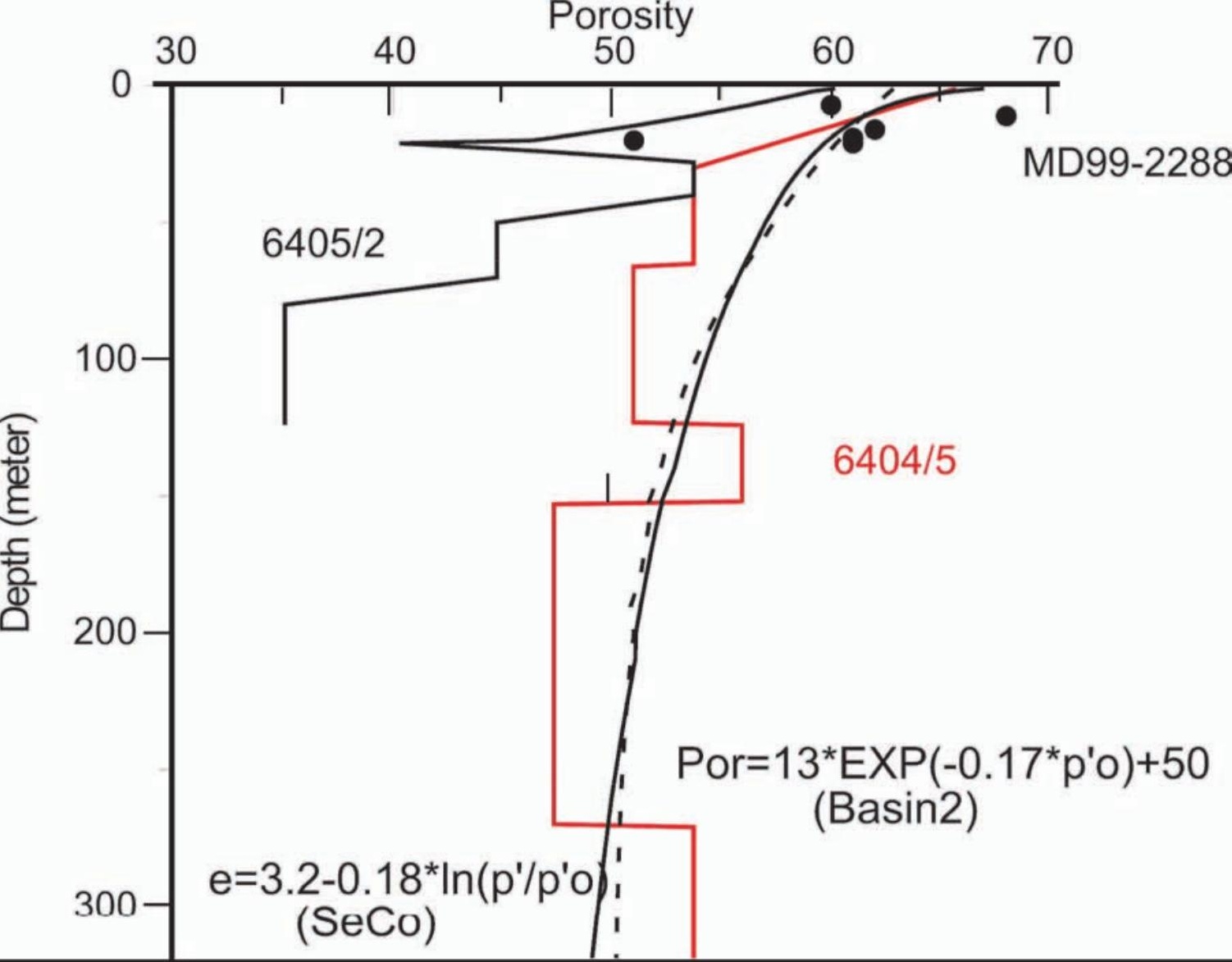



K, Permeability (m/sec)

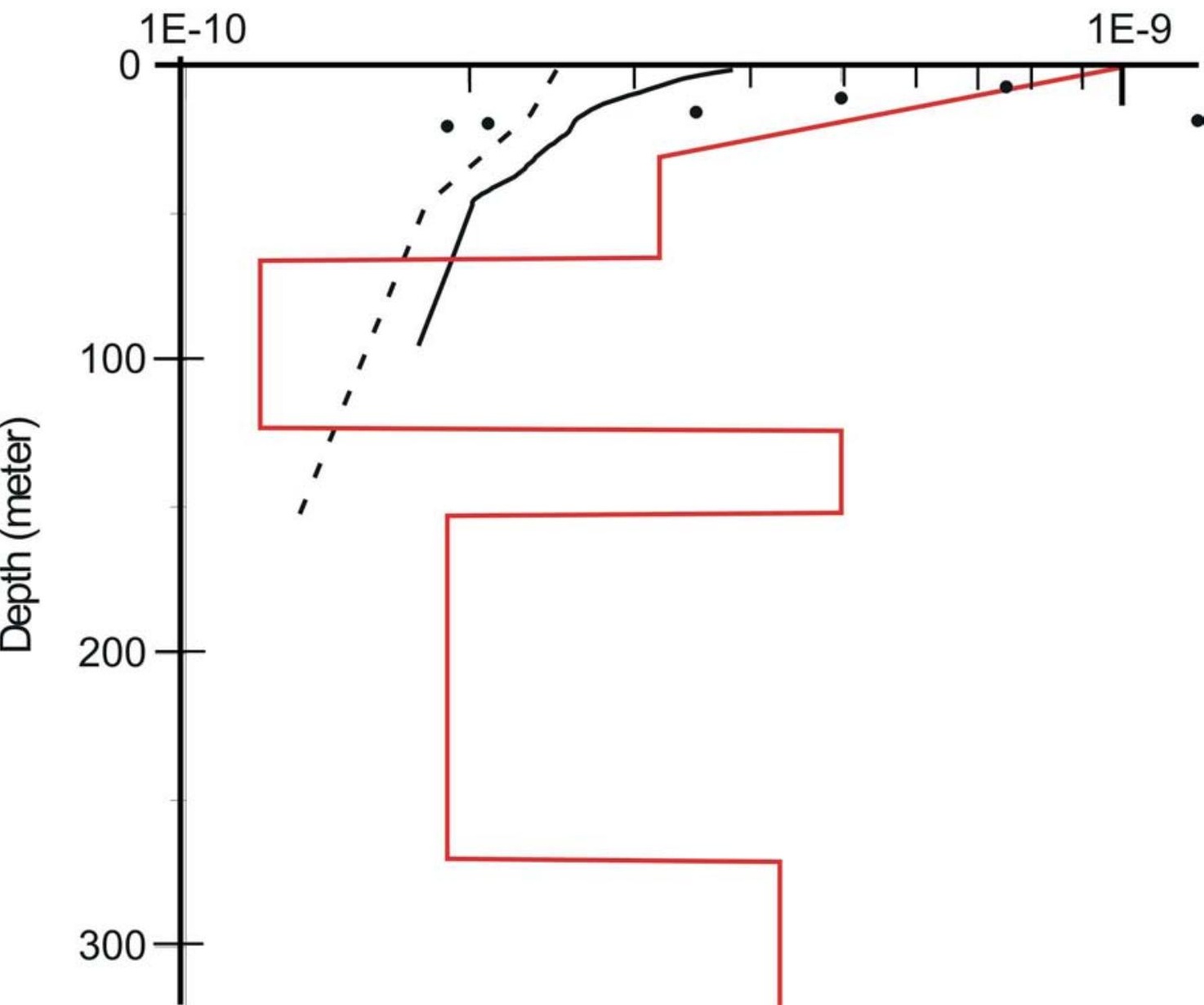


Unit weight $(\mathrm{kN} / \mathrm{m} 3)$

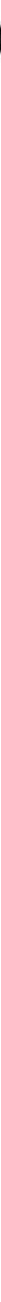




\section{Vertical effective stress $(\mathrm{kPa})$}

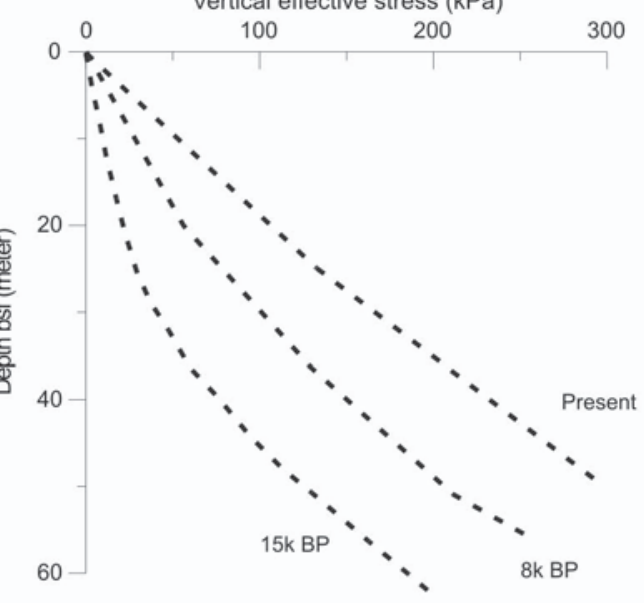

Su (kPa)

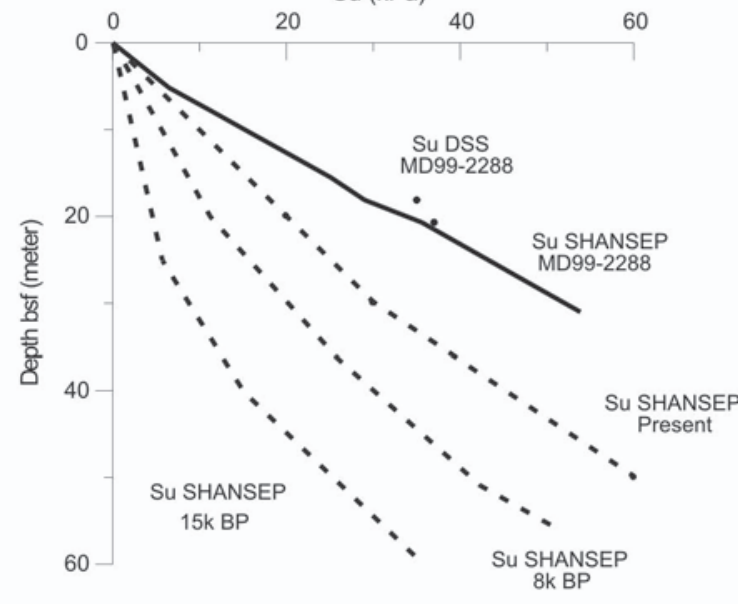

a) b) 


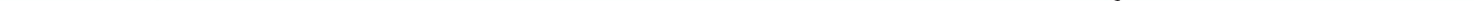




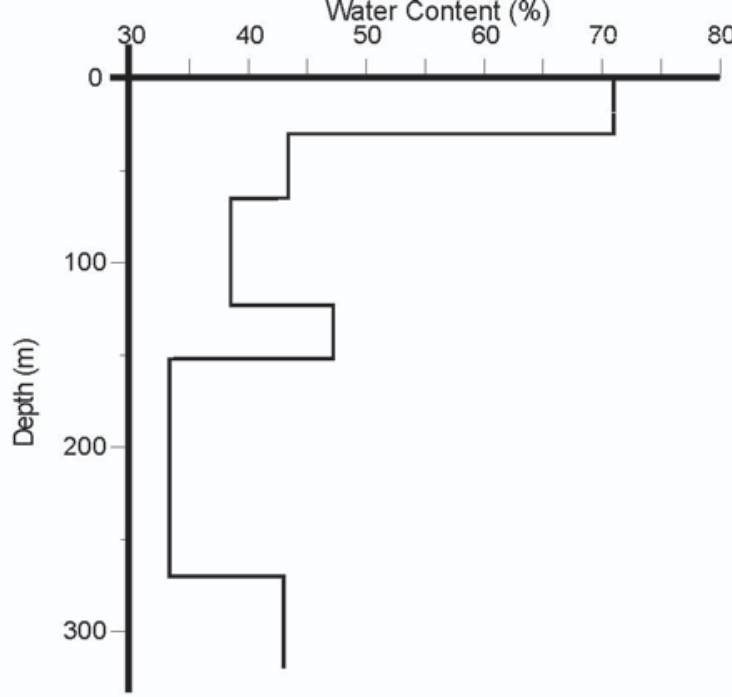


Sedimentation rate

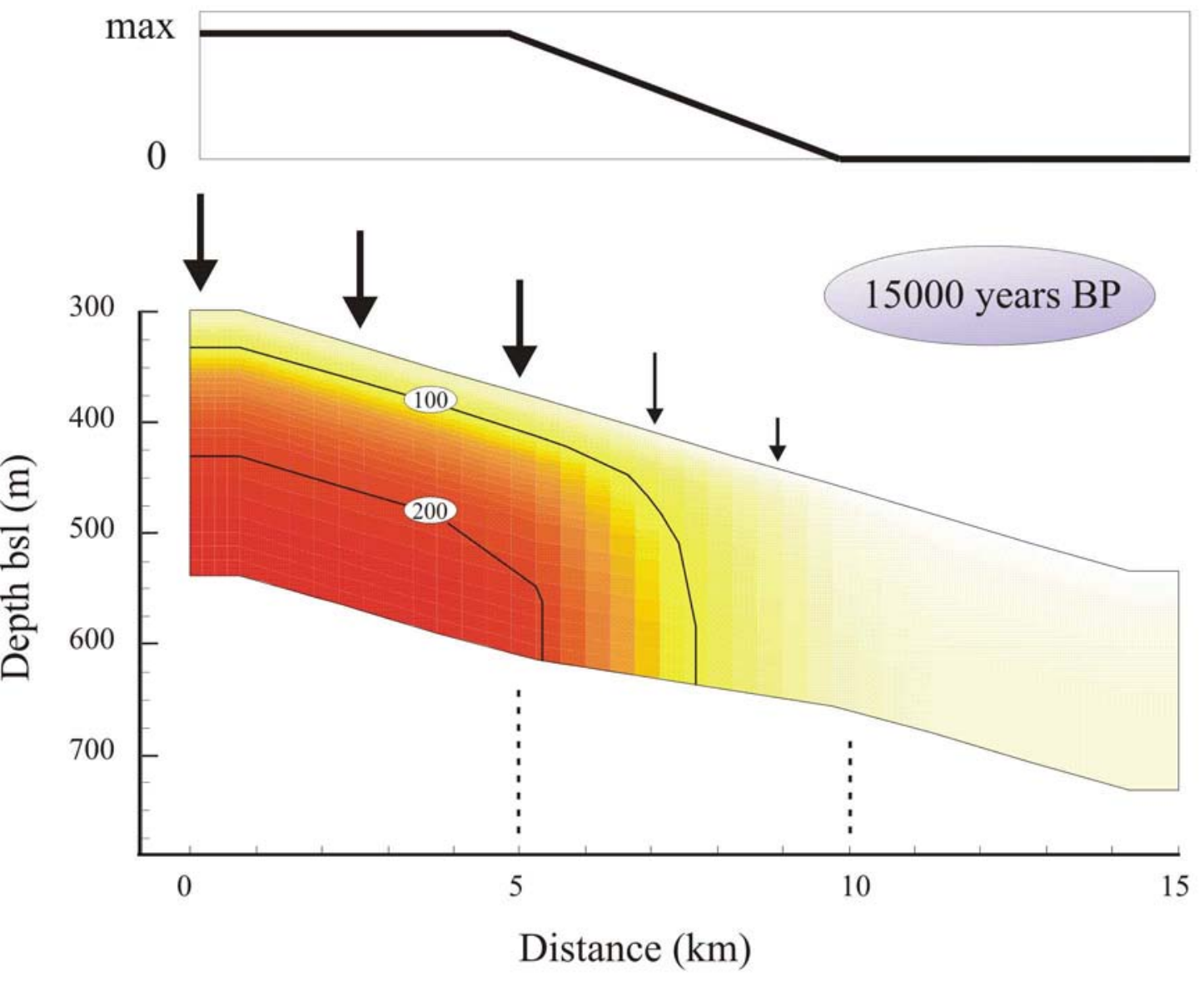

Overpressure $(\mathrm{kPa})$

$\begin{array}{lll}0 & 112.5 & 225\end{array}$




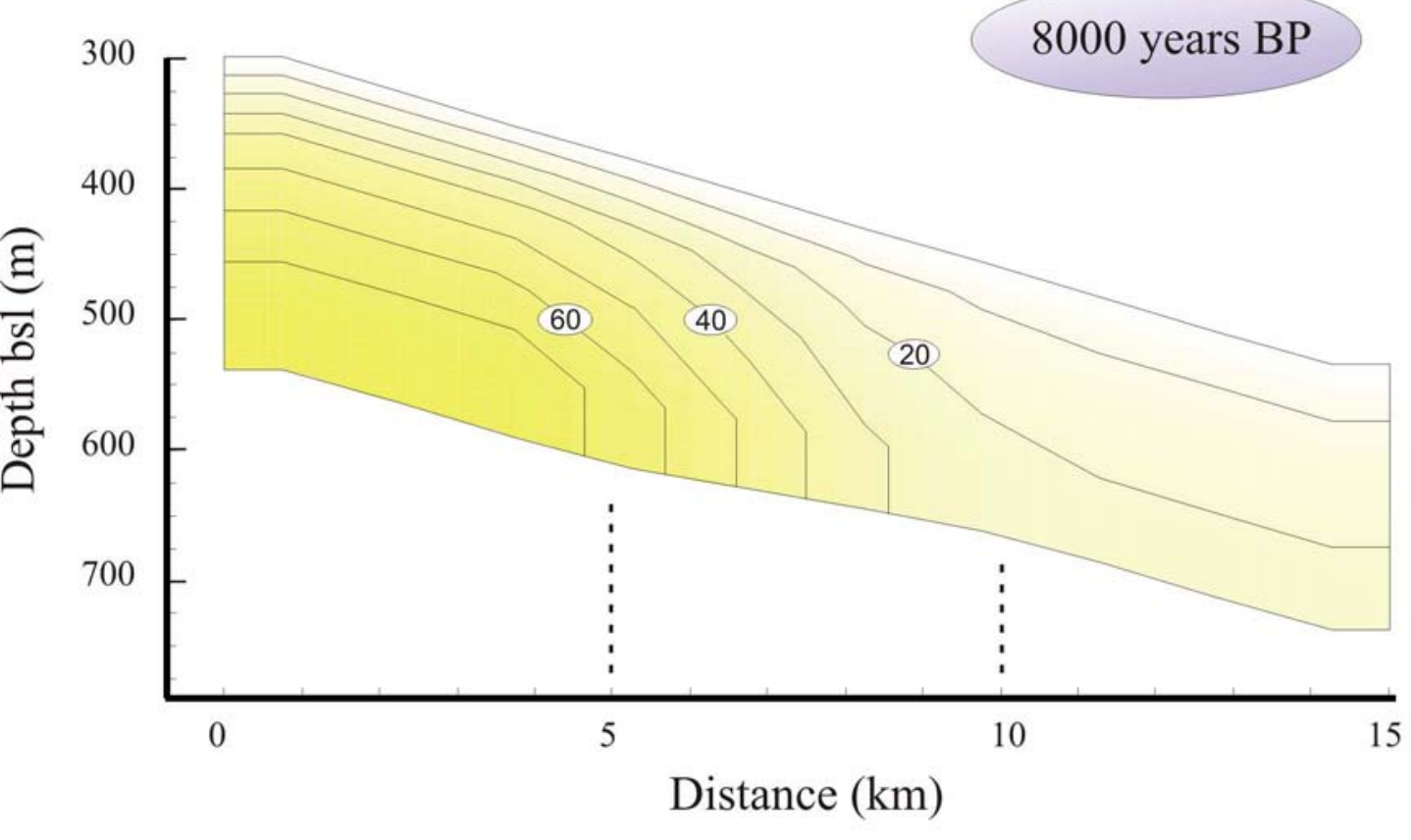

\section{Overpressure $(\mathrm{kPa})$}




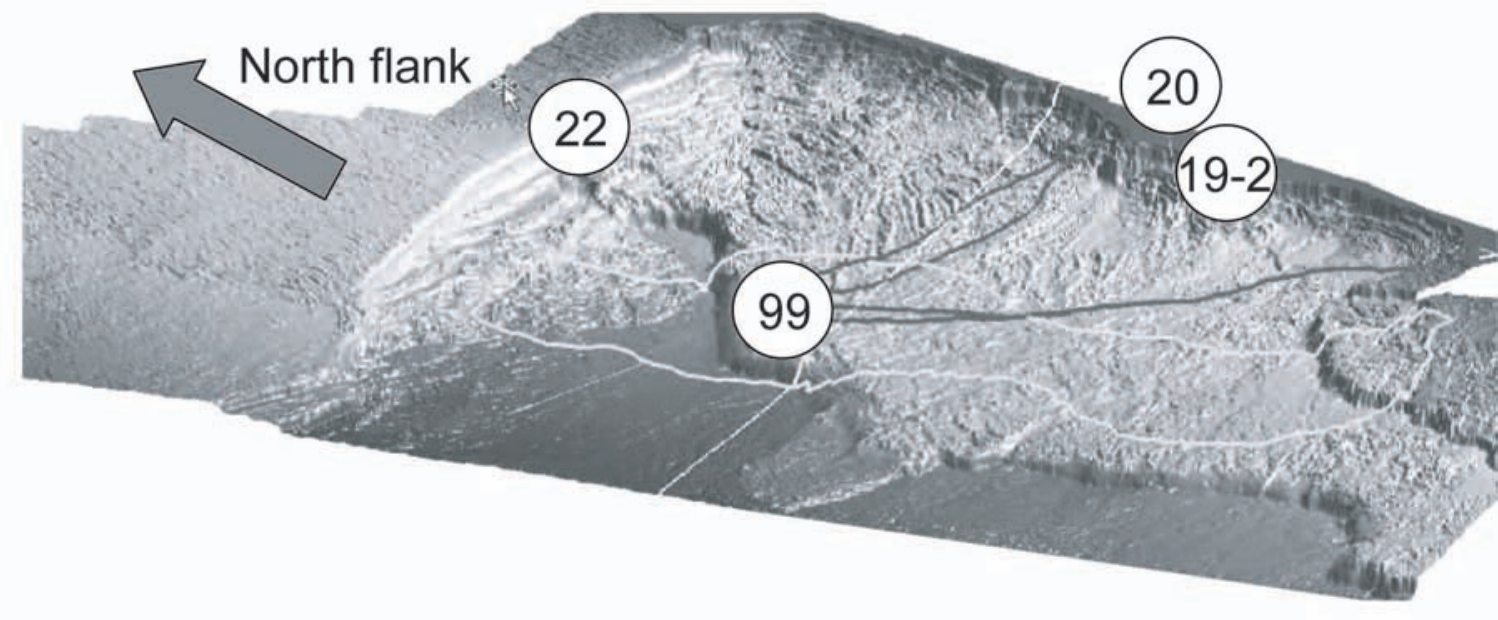




\section{HSR}

NSR

HSR: High Sedimentation Rate (rapid sedimentation)

NSR: Normal Sedimentation Rate (slow sedimentation)

Low permeability layer

Overpressure in the Sediment 